\title{
IMPACT OF VACCINATION IN THE REDUCTION OF HEPATITIS B IN PARANÁa
}

\author{
Priscila PUDELCO ${ }^{\mathrm{b}}$, Andreia Eloize KOEHLER ${ }^{\mathrm{c}}$, Lúcia Helena Linheira BISETTO ${ }^{\mathrm{d}}$
}

\section{ABSTRACT}

This study identified the impact of hepatitis B vaccine over reducing incidence of this disease in Paraná State, between 2001 and 2011, and discussed the role of nursing in immunization. Descriptive documental and quantitative research. Utilized secondary data of hepatitis B, between 2001 and 2011 and vaccination coverage of hepatitis B vaccine between 1995 and 2011 in Paraná State, available in DATASUS, SINAN and Immunization Programs. Data has been collected from May to July 2012. Included cases of hepatitis B confirmed by laboratory testing. Of the 14,434 selected cases, $81,8 \%$ was in urban residents, $86,5 \%$ belonged to 20 to 59 age group and $45,3 \%$ were infected by sexual transmission. In the correlation of vaccine coverage with the incidence, was identified reducing this rate in the range of o to 9 years old, in places with vaccination coverage's above $95 \%$. It concludes that hepatitis $\mathrm{B}$ vaccination had impact over disease reduction in Paraná State.

Descriptors: Hepatitis B. Vaccination. Epidemiology. Public Health Nursing.

\section{RESUMO}

Este estudo identificou o impacto da vacinação contra hepatite B na redução da incidência dessa doença no Paraná, de 2001 a 2011, e discutiu a atuação da enfermagem na imunização. Trata-se de pesquisa descritiva documental, quantitativa. Foram utilizados dados secundários de hepatite B, de 2001 a 201 1, e de coberturas da vacina hepatite B, de 1995 a 201 1, no Paraná, disponíveis no DATASUS, SINAN e Programa de Imunizações. Os dados foram coletados de maio a julho de 2012, incluídos casos de hepatite B confirmados laboratorialmente. Dos 14.434 casos selecionados, 81,8\% residiam na zona urbana, 86,5\% pertencia à faixa etária de 20 a 59 anos e 45,3\% foram infectados por via sexual. Na correlação das coberturas vacinais com a incidência, identificou-se a redução desta taxa nas faixas de o a 9 anos, que apresentavam coberturas vacinais acima de $95 \%$. Concluiu-se que a vacinação levou à redução da HB, no Paraná.

Descritores: Hepatite B. Vacinação. Epidemiologia. Enfermagem em Saúde Pública.

Título: Impacto da vacinação na redução da hepatite B no Paraná. Impacto da vacinação na redução da hepatite B no Paraná.

\section{RESUMEN}

Este estudio identificó el impacto de la vacuna contra hepatitis B en la reducción de esta enfermedad en Paraná, de 2001 a 201 1, y discutió la actuación de la enfermería en la inmunización. Investigación descriptiva documental, cuantitativa. Utilizados datos secundarios de hepatitis B, de 2001 a 2011 y coberturas de la vacunas hepatitis B, de 1995 a 2011, en Paraná, disponibles en el DATASUS, SINAN y en el Programa de Inmunización. Se recogieron datos de mayo-julio de 2012. Incluye los datos de hepatitis B confirmados por laboratorio. De los 14.434 casos seleccionados, 81,8\% residian en zona urbana, 86,5\% pertenecían al grupo de 20 a 59 años y 45,3\% fueron infectados sexualmente. Por alta cobertura de vacunación, ocurrió reducción de la incidencia de hepatitis B de 0-9 años que tenían la cobertura de vacunación por encima del 95\%. Se concluye que la vacunación ha impactado en la reducción de la enfermedad.

Descriptores: Hepatitis B. Vacunación. Epidemiología. Enfermería de Salud Pública.

Título: Impacto de la vacunación en la reducción de la hepatitis B en Paraná.

a Article based on the final work of the Nursing Programme at the Pontifical Catholic University of Paraná (PUCPR).

b Nurse. Degree from PUCPR. Curitiba-PR, Brazil

c Nurse. Degree from PUCPR. Curitiba-PR, Brazil

d Nurse. PhD student of Nursing at EEUSP. Faculty member of the Undergraduate Nursing Programme at the PUCPR. Curitiba-PR, Brazil 


\section{INTRODUCTION}

Hepatitis B (HB) is a health problem all over the world. According to estimates, two billion people have been infected with the HB virus (HBV), 370 million suffer from chronic infection and around one million die every year from diseases related to hepatocellular carcinoma ${ }^{(1)}$.

In Brazil, 120,343 cases of HB were notified to the Notifiable Diseases Information System of the Ministry of Health (SINAN/MS) from 1999 to 2011 , in the south-east (36.3\%), south (31.6\%), north (13.1\%), central-west (9.9\%) and north-east $(9.2 \%)$ regions. Since 2002 , the south region has recorded the highest incidence rate in the country ${ }^{(2)}$.

HB occurred with high and moderate endemicity in western Amazonia, the west and southwest of Paraná, west of Santa Catarina, Vale do Jequitinhonha, in Minas Gerais, and in some areas of the state of Mato Grosso ${ }^{(3)}$.

HBV has high infectivity and can be transmitted directly or indirectly, especially through mucous membrane or percutaneous exposure to body fluids or blood contaminated with the virus. The most frequent transmission is sexual, followed by vertical, which can be transplacental, at the moment of childbirth, during breastfeeding and when caring for a newborn child $^{(4)}$. It can also be transmitted parentally, through blood transfusions, reused syringes and unsterilized needles, piercing, tattoos, invasive medical and dental procedures, accidents with cutting or puncturing instruments and by sharing items of personal hygiene (toothbrush, shavers and razor blades) $)^{(5)}$.

HB is considered the most serious viral hepatitis as it can cause chronic liver disease, hepatic cirrhosis and hepatocellular carcinoma, annually resulting in 500 to 700 thousand deaths worldwide (6). In Brazil, from 2000 to 2011, a total of 9659 deaths were caused by this disease, mostly in the south-east $(47.3 \%)$ and south $(20.4 \%)$ regions $^{(2)}$.

In 1989, the National Immunizations Programme (PNI), seeking to prevent HB, implemented the $\mathrm{HB}$ vaccines for children under one year of age, initially in western Amazonia and then, ten years later, all over the country ${ }^{(6,8)}$. The $\mathrm{HB}$ vaccine is highly immunogenic and induces a protective response after the administration of 3 doses in more than $90 \%$ of healthy adults and $95 \%$ of healthy children and adolescents ${ }^{(3)}$.
In the 90s, endemicity for HBV infection dropped due to vaccination, considered the main form of prevention ${ }^{(7)}$. With these results, the PNI, in 2001 , extended vaccination to individuals under 20 years of age. In view of the vulnerability of some population groups to HBV infection, the vaccine was made available in 2011 to the 20 to 24 age group and, in 2012, to all individuals under $29^{(6,8)}$.

The public health system provides the HB vaccine to other vulnerable groups that were not included in the national vaccination calendar, such as manicurists, truck drivers, fire fighters, blood donors and rubbish collectors, regardless of age group $^{(8)}$.

In view of the seriousness of $\mathrm{HBV}$ infection, the Ministry of Health adopted other control measures that helped to reduce the incidence of $\mathrm{HB}$, including obligatory serum screening for HBV in haemotherapy units, and the recommendation of this screening for pregnant women ${ }^{(4,7)}$. Currently, to prevent vertical transmission, newborn babies of HBV-positive mothers receive a dose of the $\mathrm{HB}$ vaccine and anti-HB immunoglobulin after birth ${ }^{(4)}$. Considering the risk of infection during childbirth, regardless of the serological status of the mother, the PNI/MS establishes the administration of a dose of the HB vaccine to all newborn babies within the first 12 hours after birth. The vaccine prevents vertical infection in more than $90 \%$ of cases and ensures breastfeeding free of the risk of HBV infection ${ }^{(4)}$.

In the healthcare services, for the effectiveness of HB diagnosis, treatment and control measures, healthcare professionals must have knowledge of the risks of $\mathrm{HB}$, methods of transmission and the importance of prevention to orientate the general public. They must also know the health requirements of the population to propose and trigger healthcare prevention and promotion actions ${ }^{(9)}$.

In the Brazilian national health system (Sistema Único de Saúde - SUS), the immunization programme is mostly conducted by the nursing team and is based on storage, conservation and administration of immunobiologicals, planning of vaccination strategies, coordination and evaluation of vaccine coverage ${ }^{(10)}$.

To ensure effective immunization, these actions must surpass simple vaccine application, regardless of the location in which they are conducted, namely Basic Healthcare Units (UBS), hospitals, maternity 
wards or emergency units. During vaccination, it is essential to provide users with guidelines on vaccines, the requirement to comply with the vaccine calendar established by the PNI and the importance of returning to the healthcare unit in case of any adverse post-vaccination event. Assistance must be based on integrality, thus intervening in the health and sickness process of users $^{(11)}$.

In the UBS, users do not receive adequate guidelines on vaccines when nursing professionals conduct other activities in other sectors concurrently with vaccination. The practice is restricted to applying the immunobiological, which can cause fear, insecurity and indifference or resistance from the user during the vaccine schedule. Consequently, there can be a drop in vaccine coverage and increased incidence of vaccine-preventable diseases ${ }^{(11)}$.

This study addresses the incidence of $\mathrm{HB}$ and vaccination against HBV infection in Paraná, Brazil, with the aim of contributing to the practices of nurses during the vaccine programme and $\mathrm{HB}$ disease inspection, and providing information for the creation of public policies related to this field. The leading question was, has the risk of getting HB been reduced in Paraná, after the introduction of vaccination by the PNI? The objective was to identify the impact of vaccination in the reduction of HB in Paraná, from 2001 to 2011 , and to discuss the actions of nursing in immunization.

\section{METHODS}

This is a descriptive documentary study based on quantitative research. Records comprised secondary data on HB cases in Paraná from 2001 to 2011, obtained at the SUS Information Department (DATASUS) and the Notifiable Diseases Information System of the Ministry of Health (SINAN/MS). Study interest variables were age group, sex, location of residence (urban/rural) and infection mechanism. Inclusion criteria were $\mathrm{HB}$ case confirmed in laboratory, residing in Paraná, and exclusion criterion was HB case associated to other hepatitis.

Data provided by DATASUS were compared with data from SINAN/MS to identify possible differences. Given the quality of SINAM/MS records, all of which were reviewed, this database was selected for the study.

Secondary data of $\mathrm{HB}$ vaccine coverage in Paraná was also used, from 1995 to 2011 , available in the Information System of the National Immunization Programme/Ministry of Health (SI-PNI), with vaccine coverage on children under one year of age and accumulated vaccine coverage in the under 29 age group, contemplated by PNI/MS in routine vaccination.

$\mathrm{HB}$ and vaccine coverage data was collected from May to July.

The incidence rate was calculated for 100,000 inhabitants and data on residents of Paraná from 2001 to 2011, according to the Brazilian Institute of Geography and Statistics (IBGE), was collected in July 2012.

To assess the impact of vaccination on the incidence of $\mathrm{HB}$, data on $\mathrm{HB}$ and vaccine coverage were compared from 2001 to 2011.

Data were arranged in tables and graphs using TABWIN 3.2 and Microsoft ${ }^{\mathrm{TM}}$ Exce $^{\circledR}$, presented as absolute and relative frequency, and discussed according to available literature on this topic.

The study was not submitted to the Research Ethics Committee as it was based on documentary research comprising content that is available to the general public.

\section{RESULTS}

The SINAN/PR yielded 17,851 viral hepatitis notifications. Of these cases, 14,434 HB laboratoryconfirmed cases from individuals residing in Paraná were selected for the study.

A total of $91.4 \%$ records contained information on incidence according to sex, of which $6,627(50.3 \%)$ occurred in men and 6,557 (49.7\%) in women. A total of $81.8 \%$ of cases lived in urban areas.

Case distribution by year and age group showed that during the study period the 20 to 59 age group was the most affected, with $86.5 \%$ notifications (Table 1).

The source/mechanism of infection refers to the year in which transmission occurred and was identified in only $33.5 \%$ of cases, with emphasis on sexual transmission (Table 2). Data showed that during the study years, 42 children from 0 to 9 years of age were infected by HBV.

$\mathrm{HB}$ vaccine coverage on children under the age of 1 was below the standard established by the PNI/MS from 1995 to 1998, the start of vaccine implementation (Graph 1). 
Table 1 - Number of laboratory-confirmed HB cases by age group and year of notification, of residents of Paraná, 2001 to 2011.

\begin{tabular}{lcccccccccccc}
\hline \multicolumn{1}{c}{ Age Group } & $\mathbf{2 0 0 1}$ & $\mathbf{2 0 0 2}$ & $\mathbf{2 0 0 3}$ & $\mathbf{2 0 0 4}$ & $\mathbf{2 0 0 5}$ & $\mathbf{2 0 0 6}$ & $\mathbf{2 0 0 7}$ & $\mathbf{2 0 0 8}$ & $\mathbf{2 0 0 9}$ & $\mathbf{2 0 1 0}$ & $\mathbf{2 0 1 1}$ & Total \\
\hline Under 1 & 0 & 0 & 9 & 3 & 12 & 7 & 5 & 3 & 2 & 4 & 3 & 48 \\
1 to 4 years & 6 & 2 & 4 & 2 & 4 & 3 & 3 & 2 & 1 & 0 & 2 & 29 \\
5 to 9 years & 14 & 4 & 16 & 9 & 10 & 5 & 3 & 2 & 4 & 5 & 8 & 80 \\
10 to 14 years & 10 & 13 & 20 & 11 & 19 & 20 & 9 & 14 & 8 & 15 & 19 & 158 \\
15 to 19 years & 53 & 45 & 115 & 101 & 113 & 80 & 81 & 70 & 68 & 69 & 97 & 892 \\
20 to 29 years & 178 & 183 & 451 & 432 & 466 & 414 & 369 & 322 & 309 & 364 & 448 & 3936 \\
30 to 39 years & 105 & 151 & 426 & 409 & 445 & 438 & 398 & 377 & 405 & 436 & 591 & 4181 \\
40 to 49 years & 67 & 75 & 210 & 222 & 299 & 300 & 227 & 265 & 290 & 375 & 535 & 2865 \\
50 to 59 years & 21 & 30 & 93 & 94 & 142 & 151 & 124 & 160 & 152 & 188 & 348 & 1503 \\
60 to 69 years & 10 & 8 & 35 & 27 & 40 & 38 & 52 & 61 & 76 & 75 & 138 & 560 \\
70 to 79 years & 1 & 2 & 12 & 11 & 11 & 14 & 16 & 16 & 24 & 16 & 32 & 155 \\
Over 80 years & 1 & 0 & 1 & 3 & 2 & 2 & 4 & 4 & 2 & 4 & 4 & 27 \\
\hline Total & $\mathbf{4 6 6}$ & $\mathbf{5 1 3}$ & $\mathbf{1 3 9 2}$ & $\mathbf{1 3 2 4}$ & $\mathbf{1 5 6 3}$ & $\mathbf{1 4 7 2}$ & $\mathbf{1 2 9 1}$ & $\mathbf{1 2 9 6}$ & $\mathbf{1 3 4 1}$ & $\mathbf{1 5 5 1}$ & $\mathbf{2 2 2 5}$ & $\mathbf{1 4 4 3 4}$ \\
\hline
\end{tabular}

Source: SINAN/MS

Table 2 - Frequency of confirmed HB cases, by source/mechanism of infection and year of notification, Paraná, 2001 to 2011.

\begin{tabular}{lcccccccccccccc}
\hline $\begin{array}{l}\text { Source/Mech-. } \\
\text { of Infection }\end{array}$ & $\mathbf{2 0 0 1}$ & $\mathbf{2 0 0 2}$ & $\mathbf{2 0 0 3}$ & $\mathbf{2 0 0 4}$ & $\mathbf{2 0 0 5}$ & $\mathbf{2 0 0 6}$ & $\mathbf{2 0 0 7}$ & $\mathbf{2 0 0 8}$ & $\mathbf{2 0 0 9}$ & $\mathbf{2 0 1 0}$ & $\mathbf{2 0 1 1}$ & \multicolumn{2}{c}{ Total } \\
\hline Sexual & 15 & 34 & 170 & 168 & 187 & 224 & 268 & 258 & 283 & 251 & 333 & $\mathbf{2 1 9 1}$ & $\mathbf{4 5 , 3}$ \\
Others & 63 & 49 & 74 & 78 & 108 & 92 & 45 & 58 & 62 & 69 & 115 & $\mathbf{8 1 3}$ & $\mathbf{1 6 , 8}$ \\
Home & 7 & 6 & 100 & 57 & 61 & 55 & 53 & 51 & 53 & 65 & 154 & $\mathbf{6 6 2}$ & $\mathbf{1 3 , 7}$ \\
Vertical & 3 & 4 & 20 & 30 & 40 & 60 & 44 & 55 & 56 & 55 & 76 & $\mathbf{4 4 3}$ & $\mathbf{9 , 1}$ \\
Dental treat. & -- & -- & -- & -- & -- & -- & 33 & 36 & 27 & 67 & 79 & $\mathbf{2 4 2}$ & $\mathbf{5}$ \\
Dental/Surg. & 0 & 5 & 25 & 24 & 36 & 22 & 8 & 2 & 1 & 12 & 11 & $\mathbf{1 4 6}$ & $\mathbf{3}$ \\
treat. & & & & & & & & & & & & & & \\
Transfusion & 0 & 1 & 8 & 20 & 26 & 25 & 25 & 19 & 28 & 44 & $\mathbf{2 1 5}$ & $\mathbf{4 , 5}$ \\
Inject. Drug use & 0 & 0 & 6 & 5 & 7 & 6 & 3 & 13 & 8 & 9 & 19 & $\mathbf{7 6}$ & $\mathbf{1 , 6}$ \\
Work accident & 0 & 1 & 3 & 8 & 5 & 5 & 9 & 3 & 8 & 3 & 7 & $\mathbf{5 2}$ & $\mathbf{1}$ \\
\hline Total & $\mathbf{8 8}$ & $\mathbf{1 0 0}$ & $\mathbf{4 0 6}$ & $\mathbf{3 8 9}$ & $\mathbf{4 6 4}$ & $\mathbf{4 9 0}$ & $\mathbf{4 8 8}$ & $\mathbf{5 0 1}$ & $\mathbf{5 1 7}$ & $\mathbf{5 5 9}$ & $\mathbf{8 3 8}$ & $\mathbf{4 8 4 0}$ & $\mathbf{1 0 0}$ \\
\hline & & & & & & & & & & & &
\end{tabular}

Source: SINAN/MS

In relation to vaccine coverage by age group, records showed low coverage in the 15 to 19 age group and the 25 to 29 age group (Graph 2).

The highest $\mathrm{HB}$ incidence rates were in the 20 to 69 age group (Table 3 ).

\section{DISCUSSION}

The search for HB cases in the SINAN/PR resulted in 14,434 records, with similar distribution between men and women. However, there was a 


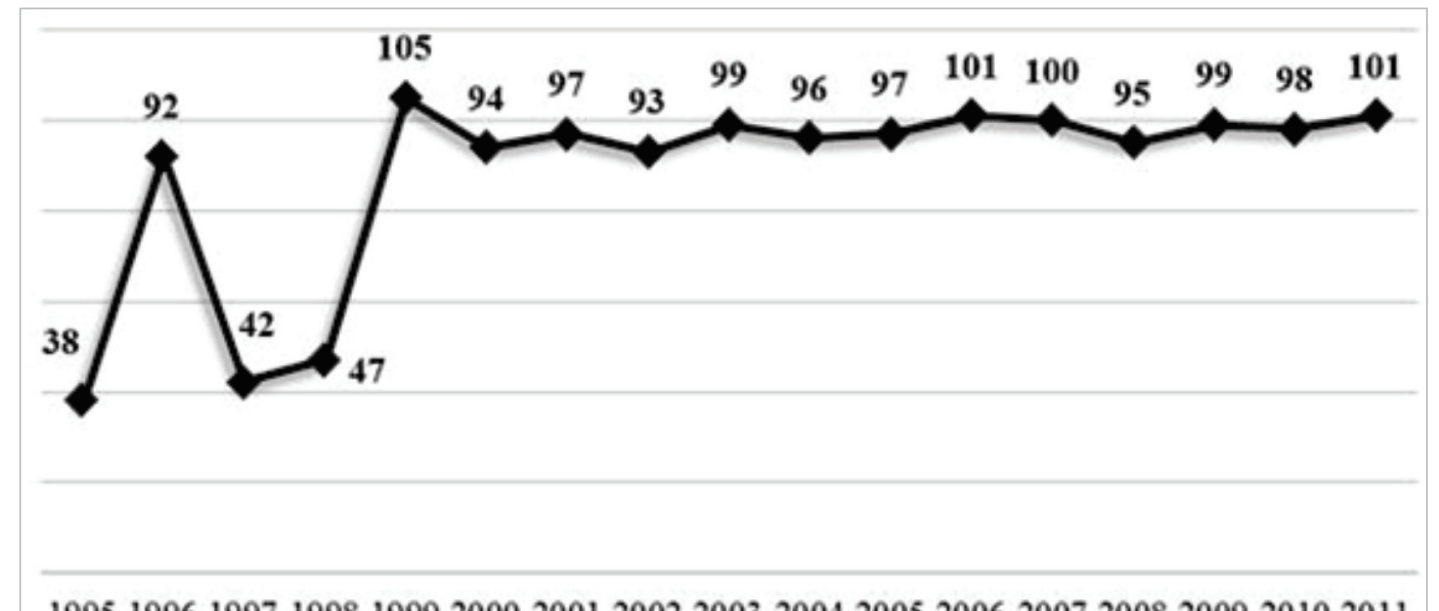

19951996199719981999200020012002200320042005200620072008200920102011

Graph 1 - HB vaccine coverage of children under 1 year of age, Paraná, 1995-2011. Source: PNI/MS

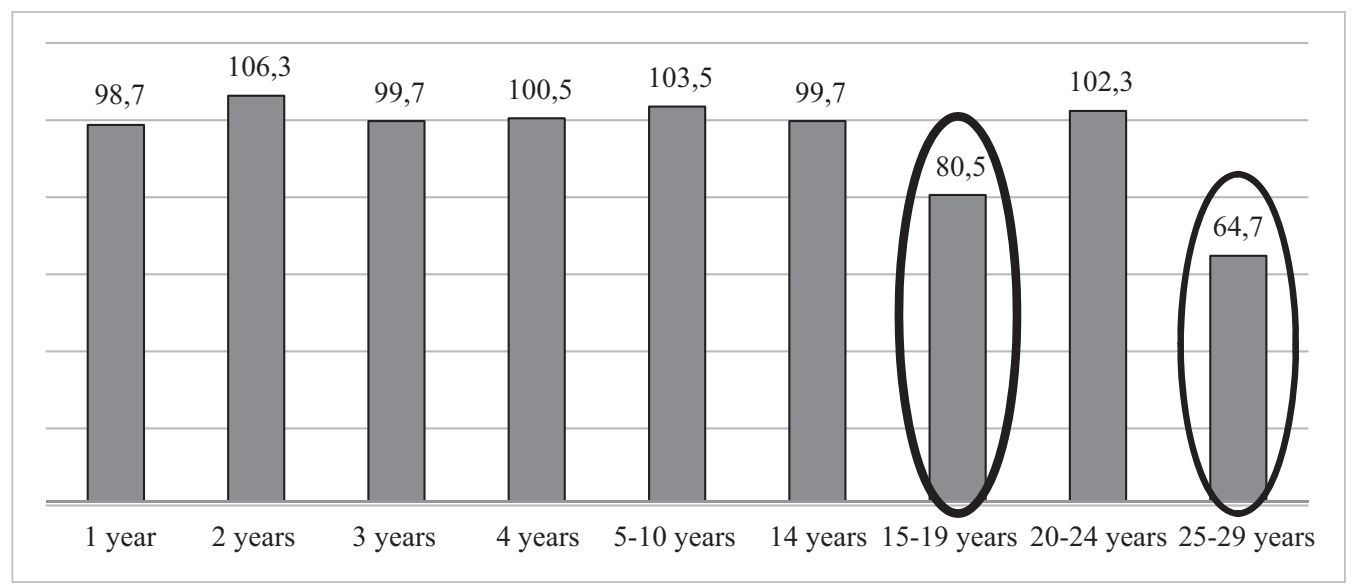

Graph 2 - Accumulated HB vaccine coverage, by age group from 1 to 29 years, Paraná, 1995-2011. Source: PNI/MS

significant difference in location of residence, being that the majority $(81.8 \%)$ lived in urban areas, corroborating findings of a study conducted in Chapecó $^{(12)}$, and can be related to the perception of individuals of the health and sickness process and access to healthcare services.

A study on medical care showed that residents of urban areas mostly used healthcare services for routine exams and prevention due to easy access and the influence of private healthcare plans. Residents of rural areas only sought healthcare services when they felt sick, due to difficult access to testing, treatment and rehabilitation. Another factor that can influence this behaviour are biologicists prac- tices that target disease and are still present in the SUS ${ }^{(19)}$. These practices hinder early HBV diagnosis as most cases are asymptomatic and require epidemiologic investigation with complementary tests ${ }^{(12)}$.

The 20 to 59 age group was the most affected by HB, with $86.5 \%$ of notifications (Table 1). This tendency was also found in other studies conducted in Brazil that showed that HBV onset was higher in individuals of the 20 to 40 age group, which is the sexually active population ${ }^{(14)}$, corresponding to $38.6 \%$ of cases confirmed in the southern region of Brazil (2).

In 2011, there was an increase in the number of cases in adolescents, considered a vulnerable 
Table 3 - HB incidence rate (100,000 inhabitants), by age group and notification year, Paraná, 2001 to 2011.

\begin{tabular}{lccccccccccc}
\hline \multicolumn{1}{c}{ Age Group } & $\mathbf{2 0 0 1}$ & $\mathbf{2 0 0 2}$ & $\mathbf{2 0 0 3}$ & $\mathbf{2 0 0 4}$ & $\mathbf{2 0 0 5}$ & $\mathbf{2 0 0 6}$ & $\mathbf{2 0 0 7}$ & $\mathbf{2 0 0 8}$ & $\mathbf{2 0 0 9}$ & $\mathbf{2 0 1 0}$ & $\mathbf{2 0 1 1}$ \\
\hline Under 1 & 0,0 & 0,0 & 5,0 & 1,6 & 6,4 & 3,7 & 3,3 & 2,1 & 1,4 & 2,8 & 2,1 \\
1 to 4 years & 0,8 & 0,3 & 0,5 & 0,3 & 0,5 & 0,4 & 0,4 & 0,3 & 0,2 & 0,0 & 0,3 \\
5 to 9 years & 1,5 & 0,4 & 1,7 & 0,9 & 1,0 & 0,5 & 0,3 & 0,2 & 0,4 & 0,7 & 1,0 \\
10 to 14 years & 1,1 & 1,4 & 2,1 & 1,1 & 1,9 & 2,0 & 1,0 & 1,5 & 0,9 & 1,7 & 2,1 \\
15 to 19 years & 5,5 & 4,6 & 11,7 & 10,2 & 11,1 & 7,8 & 8,5 & 7,4 & 7,2 & 7,4 & 10,4 \\
20 to 29 years & 10,5 & 10,7 & 26,0 & 24,6 & 25,9 & 22,7 & 19,7 & 17,2 & 16,4 & 20,4 & 25,0 \\
30 to 39 years & 6,8 & 9,7 & 27,2 & 25,8 & 27,4 & 26,6 & 24,7 & 23,3 & 24,7 & 26,9 & 36,2 \\
40 to 49 years & 5,8 & 6,4 & 17,8 & 18,6 & 24,5 & 24,3 & 16,1 & 18,4 & 19,8 & 25,6 & 36,2 \\
50 to 59 years & 2,8 & 4,0 & 12,1 & 12,1 & 18,0 & 18,9 & 12,7 & 15,8 & 14,5 & 17,4 & 32,0 \\
60 to 69 years & 2,1 & 1,6 & 7,1 & 5,4 & 7,9 & 7,4 & 8,8 & 9,9 & 11,9 & 11,2 & 20,6 \\
70 to 79 years & 0,4 & 0,8 & 4,8 & 4,3 & 4,2 & 5,4 & 4,9 & 4,7 & 6,8 & 4,5 & 8,9 \\
over 80 years & 1,2 & 0,0 & 1,1 & 3,4 & 2,2 & 2,2 & 3,1 & 2,9 & 1,3 & 2,7 & 2,7 \\
\hline Total & $\mathbf{4 , 8}$ & $\mathbf{5 , 2}$ & $\mathbf{1 4 , 1}$ & $\mathbf{1 3 , 2}$ & $\mathbf{1 5 , 2}$ & $\mathbf{1 4 , 2}$ & $\mathbf{1 2 , 3}$ & $\mathbf{1 2 , 2}$ & $\mathbf{1 2 , 5}$ & $\mathbf{1 4 , 8}$ & $\mathbf{2 1 , 2}$ \\
\hline
\end{tabular}

Source: SINAN/MS

population group due to its characteristics and tendency for illegal drug use, unprotected sex and multiple partners, resulting in a high risk of HBV exposure ${ }^{(5,15)}$ (Table 1). The positive rates in adolescence is a cause for concern because they are maintained during adulthood ${ }^{(5,15)}$.

In relation to the source/mechanism of infection (Table 2), in $66.5 \%$ of records this information was not provided, probably because the user did not know how he or she was infected or due to deviations in the quality of collected data. This finding is greater than the $60.4 \%$ of users registered in the southern region and $30 \%$ of users found in studies conducted in other countries ${ }^{(1)}$.

HBV infection predominantly occurred through sexual transmission (45\%) (Table 2), showing a similar tendency to data obtained in a study conducted in Pará(15), but higher than results found in the southern region of $\mathrm{Brazil}^{(2)}$. In 2011, the increase in number of infected cases through blood transfusions, vertical transmission and work accidents requires investigation, as there are public health policies that target the inspection of blood and haemoderivatives, child care and prenatal care for mothers, care during birth and post-natal care, worker's health and immunization (Table 2).

It should be noted that $9.1 \%$ of cases that identified source/mechanism of infection (Table 2) were from vertical transmission, considering that HBV of the newborn has a 90\% chance of becoming chronic, which could be avoided with vaccination $^{(4)}$. During this period, the HB vaccine was already implemented for newborn babies in maternity hospitals and wards during the first 12 hours after birth with a protective efficiency of $95 \%{ }^{(3-4)}$.

These findings show the need to reinforce immunization actions in hospitals and maternity wards, with involvement of healthcare professionals in permanent awareness activities on this topic. There is a report of unsatisfactory knowledge of obstetricians and nursing professionals on the use of immunoglobulin and the $\mathrm{HB}$ vaccine, which could affect the quality of provided services ${ }^{(4,6)}$.

HBV infection through work accidents can also be avoided with vaccination, although some employees in the infirmary stated they were not vaccinated because they receive little information on $\mathrm{HB}$ and do not have time to go to a healthcare unit (UBS) $)^{(6)}$, which reinforces the need for actions that target worker's health.

Research at a hospital found that the adoption of vaccine accessibility measures for infirmary staff, such as applying vaccines at the workplace or during work hours, awareness strategies that inform and encourage, and the widespread promotion of vaccination, resulted in high vaccine coverage ${ }^{(17)}$. 
The assessment of $\mathrm{HB}$ vaccine coverage in children under the age of one (Graph 1) showed coverage below standards established by the PNI/ MS during the first years of vaccine implementation caused by, among other things, a shortage of this product ${ }^{(12)}$. After 1999, vaccine coverage rose and remained steady until 2011 due to nursing activities in the immunization programme, especially in the UBS, where there is a continuity of the HB vaccine scheme initiated at the maternity hospital.

A study conducted in two UBS identified the actions of nurses in the vaccination room in relation to conservation, storage and administration of immunobiologicals, and the provision of user guidelines. Nurses participated in this process through team training, healthcare awareness activities during growth and development supervision of children, in groups for expectant mothers and home visits ${ }^{(11)}$.

The Ministry of Health annually calculates accumulated $\mathrm{HB}$ vaccine coverage to identify the residual susceptible population and evaluate the need to initiate intensified vaccination and/or expand the age group of routine vaccination.

Although Paraná maintains high vaccine coverage in children under the age of one, accumulated coverage from 1995 to 2011 (Graph 2) has dropped in the 15 to 19 age group (80.6\%) and the 25 to 29 age group (64.8\%) due to non-vaccination of people contemplated in the basic vaccine calendar, resulting in an accumulation of susceptible individuals. A study conducted in Piauí also identified low HB vaccine coverage in adolescents. Surveying of possible causes showed lost vaccination opportunities during attendance at the UBS and lack of information on the vaccine ${ }^{(16)}$.

The accumulation of activities of nursing teams that provide care and administer healthcare services can lead to the scarcity of awareness practices that adolescents and adults mentioned as being the motive for non-vaccination ${ }^{(6,11)}$. To improve vaccine coverage of this population group, immunization practices must be restructured and co-responsibility for protection must be discussed. In spite of the availability of immunobiologicals, the decision to have a vaccine is individual ${ }^{(16)}$.

The high vaccine coverage obtained in the 20 to 24 age group is a reflection of the population's response to the vaccination campaign for this age group in 2011.
Analysis of $\mathrm{HB}$ incidence in Paraná from 2001 to 2011 (Table 3) showed lower values in the 0 to 9 age group, which have high vaccine coverage (Graph 2). In the remaining age groups, the increased incidence can be justified by nonvaccination of population groups that were not contemplated in the basic vaccination calendar since vaccine implementation. The situation of these segments can also be worsened by the high risk of HBV exposure via sexual transmission.

Although the 10 to 14 age group has high accumulated vaccine coverage (Graph 2), many children under one year of age were not vaccinated in a timely manner in 1997 and 1998 (Graph 1), which generated an accumulation of people susceptible to HBV infected during this period.

The vaccine coverage correlation (Graphs 1 and 2) with HB incidence (Table 3) showed the impact of vaccination in the reduction of HB in Paraná, confirmed by results from other studies that show vaccine efficiency in $90 \%$ of healthy adults and more than $95 \%$ of healthy children and adolescents ${ }^{(3)}$.

Data found in this study corroborate research results that identified a significant reduction in the prevalence of chronic $\mathrm{HB}$ carriers in western Amazonia, possibly linked to vaccination ${ }^{(3)}$.

The impact of vaccination in the reduction of $\mathrm{HB}$ incidence was also identified in studies conducted in Taiwan and Italy. In Taiwan, after the start of vaccination, there was a reduction of $75 \%$ in the incidence of hepatocellular carcinoma in children from 6 to 9 years of age, and of $68 \%$ in mortality due to fulminant hepatitis. In Italy, after the introduction of $\mathrm{HB}$ vaccines for children and adolescents, the incidence of hepatocellular carcinoma dropped from 11 out of every 100,000 cases, recorded in 1987, to 1.6 out of every 100,000 cases, recorded in 2006. In the south of this country, previously considered hyperendemic, prevalence dropped from $13.4 \%$ to $0.9 \% 20$ years after the vaccine was introduced ${ }^{(1)}$.

In Paraná, in 2011, an increase in the records of $\mathrm{HB}$ incidence can be associated to improved disease control actions for viral hepatitis and the quality of information from the SINAN/MS.

\section{CONCLUSIONS}

This study identified the impact of vaccination on the reduction of the incidence of $\mathrm{HB}$ cases in 
Paraná in the 0 to 9 age group, and confirmed the efficiency of the vaccine as a control measure for this disease.

It also provided extended knowledge on the epidemiological profile of $\mathrm{HB}$ and $\mathrm{HB}$ vaccine coverage in the state, and discussions on nursing practices for immunization.

It was therefore concluded that maintenance of high vaccine coverage is essential for effective HB control, and that nursing actions significantly contributed to the obtainment of these results.

Active participation of the nursing team was detected in immunization programme coordination, planning, evaluation and follow-up of vaccine coverage, in vaccine administration, provision of user guidelines, and vaccination activities outside the UBS.

The nursing team also helped to maintain high vaccine coverage by providing users with guidelines on the vaccine scheme during prenatal care, nursing consultations, in groups for expectant mothers and home visitations.

It is important to emphasize the importance of reinforcing the work of nursing professionals outside these areas and finding alternatives for the inclusion of the most vulnerable groups currently without access to vaccination and information by means of healthcare promotion and prevention actions that contribute to $\mathrm{HB}$ control.

The HB scenario in Paraná, with an increased number of cases from vertical transmission, transfusion and work accidents, reveals the need to implement immunization programmes in maternity wards, hospitals, blood banks and other healthcare services with greater involvement of healthcare professionals to allow vaccination of the population and healthcare providers, and orientation on HB prevention through vaccination.

In light of these findings, which identified a high risk of $\mathrm{HBV}$ infection in the 30 to 59 age group, currently without access to routine vaccination, the PNI should consider the inclusion of this age in the national vaccination calendar.

Study limitations were related to secondary HB data and sub-notification of cases, mostly caused by the characteristics of this infection, which moves silently, and the passive health inspection system adopted by the Ministry of Health. Furthermore, there were possible deviations in the quality of information from the SINAN due to incomplete notification records.

\section{REFERENCES}

1 Michel ML, Tiollais P. Hepatitis B vaccines: protective efficacy and therapeutic potential. Pathol Biol [Internet]. 2010 [citado 2013 ago 6]; 58(4):288-95. Available in: http://www.sciencedirect.com/science/ article/pii/So369811410000246

2 Ministério da Saúde (BR), Secretaria de Vigilância em Saúde, Departamento de DST, AIDS e Hepatites Virais. Boletim epidemiológico: hepatites virais. Brasília; 2012. [citado 2012 nov 12]. Available in: http://www.aids.gov.br/sites/ default/files/anexos/publicacao/2012/51820/ boletim_epidemiol_gico_hepatites_virais_2012_ ve_12026.pdf

3 Moraes JC, Luna EJA, Grimaldi RA. Imunogenicidade da vacina brasileira contra hepatite B em adultos. Rev Saúde Publica [Internet]. 2010 [citado 2012 set 13]; 44(2):353-9. Available in: http://www.scielo.br/ $\mathrm{pdf} / \mathrm{rsp} / \mathrm{v} 44 \mathrm{n} 2 / 17 . \mathrm{pdf}$

4 Conceição JS, Diniz-Santos DR, Ferreira CD, Paes FN, Melo CN, Silva LR. Conhecimento dos obstetras sobre a transmissão vertical da hepatite B. Arq Gastroenterol [Internet]. 2009 [citado 2012 ago 27]; 46(1):57-61. Available in: http://www.scielo.br/pdf/ ag/v46n1/15.pdf

5 Attilio JS, Rodrigues FP, Renovato RD, Sales CM, Alvarenga MRM, Moreira MT, et al. Cobertura vacinal contra hepatite B entre usuários de drogas ilícitas. Acta Paul Enferm [Internet]. 2011 [citado 2013 ago 5]; 24(1):101-6. Available in: http://www. scielo.br/pdf/ape/v24n1/v24n1a15.pdf

6 Carvalho AMC, Araújo TME. Análise da produção científica sobre hepatite B na pós-graduação de enfermagem. Rev Bras Enferm [Internet]. 2008 [citado 2012 nov 15]; 61(4):518-22. Available in: http:// www.scielo.br/pdf/reben/v61n4/20.pdf

7 Tauil MC, Amorim TR, Pereira GFM, Araújo WN. Mortalidade por hepatite viral B no Brasil, 20002009. Cad Saúde Pública [Internet]. 2012 [citado 2012 set 25]; 28(3):472-8. Available in: http://www. scielo.br/pdf/csp/v28n3/o7.pdf

8 Ministério da Saúde (BR) [Internet]. Brasília (DF): Imunização: saúde amplia faixa etária para vacinação de hepatite B; [atualizado 2012; citado 2012 nov 4]. Available in: http://portalsaude.saude.gov.br/ portalsaude/noticia/3890/162/saude-amplia-faixa-etaria-para-vacinacao-de-hepatite-b.html 
9 Queiroz AS, Moura ERF, Nogueira PSF, Oliveira NC, Pereira MMQ. Atuação da equipe de enfermagem na sala de vacinação e suas condições de funcionamento. Rev RENE [Internet]. 2009 [citado 2012 nov 6];10(4):126-35. Available in: http://www.revistarene.ufc.br/vol10n4_pdf/v10n4a15.pdf

10 Bisetto LHL, Cubas MR, Malucelli A. A prática da enfermagem frente aos eventos adversos pós-vacinação. Rev Esc Enferm USP [Internet]. 2011 [citado 2012 nov 9]; 45(5):1128-34. Available in: http:// www.scielo.br/pdf/reeUSp/v45n5/v45n5a14.pdf

11 Oliveira VG, Pedrosa KK, Monteiro AI, Santos AD. Vacinação: o fazer da Enfermagem e saber das mães e/ou cuidadores. Rev RENE [Internet]. 2010 [citado 2012 nov 12];11:133-41. Available in: http:// www.revistarene.ufc.br/revista/index.php/revista/ article/view/478/pdf_1

12 Moschetta F, Peres MA. Perfil epidemiológico dos portadores de hepatite B no município de Chapecó-SC no período de 1996 a 2006 [Internet〕. Florianópolis: Diretoria de Vigilância Epidemiológica; 2007 [citado 2012 set 5]; Available in: http://www.dive.sc.gov. br/conteudos/publicacoes/tcc/Perfil_epidemiologico_dos_portadores_de_hepatite_B_Chapeco.pdf

13 Kassouf AL. Acesso aos serviços de saúde nas áreas urbana e rural do Brasil. Rev Econ Sociol [Internet]. 2005 [citado 2012 nov 13];43(1):29-44. Available in: http://www.scielo.br/pdf/resr/v43n 1/25834.pdf

\section{Author's address / Endereço do autor / Dirección del autor}

Lúcia Helena Linheira Bisetto

Escola de Saúde e Biociências, Curso de Graduação em Enfermagem

Rua Imaculada Conceição, 1155, Prado Velho

80242-980, Curitiba, PR

E-mail: lucia.bisetto@pucpr.br
14 Anastácio J, Johann AA, Silva AL, Colli SJRC, Panagio LA. Prevalência do vírus da hepatite B em indivíduos da região centro-ocidental do Paraná, Brasil. SaBios: Rev Saúde e Biol [Internet]. 2008 [citado 2012 nov 13]; 3(2):10-5. Available in: http:// revista. grupointegrado.br/revista/index.php/sabios2/article/view/119/44

15 Aquino JA, Pegado KA, Barros LP, Machado LFA. Soroprevalência de infecções por vírus da hepatite B e vírus da hepatite $\mathrm{C}$ em indivíduos do Estado do Pará. Rev Soc Bras Med Trop [Internet]. 2008 [citado 2013 ago 4];41(1):334-7. Available in: http://www. scielo.br/pdf/rsbmt/v41n4/a03v41n4.pdf

16 Carvalho AMC, Araújo TME. Fatores associados à cobertura vacinal em adolescentes. Acta Paul Enferm [Internet]. 2010 [citado 2013 ago 5];23(6):796802. Available in: http://www.scielo.br/pdf/ape/ v23n6/13.pdf

17 Vieira RHG, Erdmann AL, Andrade SR, Freitas PF. Vacinação contra Influenza em profissionais de enfermagem: realidade e desafios. Acta Paul Enferm [Internet]. 2012 [citado 2013 ago 31]; 25(spe2):1049. Available in: http://www.scielo.br/pdf/ape/ v25nspe2/pt_16.pdf

18 Pudelco P, Koehler AE. Impacto da vacinação na redução da hepatite $\mathrm{B}$ no Paraná [monografia]. Curitiba (PR): Curso de Enfermagem, Pontifícia Universidade Católica do Paraná; 2012.
Received: 13.03.2013

Approved: 20.01.2014 